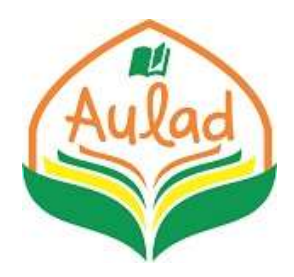

Contents list avaliable at Directory of Open Access Journals (DOAJ)

Aulad : Journal on Early Childhood

Vol 4 No. 1 2021, Pages 59 - 66

ISSN : 2655-4798 (Printed); 2655-433X (Online)

Journal Homepage: https://aulad.org/index.php/aulad

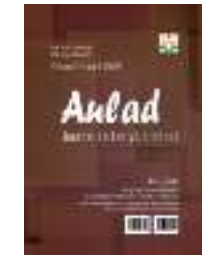

\title{
Peningkatan Kemampuan Kognitif Anak Usia Dini melalui Media Pembelajaran Beam Number dari Kardus Bekas
}

\author{
Nurlaela ${ }^{1 凶}$, Suyadi $^{2}$ \\ Pendidikan Islam Anak Usia Dini, Universitas Islam Negeri Sunan Kalijaga Yogyakarta, Indonesia ${ }^{(1,2)}$ \\ DOI: $10.31004 /$ aulad.v4i1.94
}

$\triangle$ Corresponding author:

[19204030051@student.uin-suka.ac.id]

\begin{abstract}
Article Info
Abstrak

Kata kunci:

Kognitif;

Media;

Masa pra sekolah merupakan tahapan yang sangat berarti dalam kehidupan

Beam number

seseorang, yang sangat mempengaruhi tahap perkembangan selanjutnya maka diperlukan perhatian lebih pada aspek-aspek perkembangan yang ada. Aspek perkembangan kognitif adalah aspek yang penting dikembangkan secara maksimal. Pengembangan aspek kognitif salah satunya dapat dilakukan melalui media beam number. Tujuan Penelitian ini guna untuk mengetahui penerapan atau pelaksanaan media beam number dalam kemampuan mengenal angka 1-10 untuk anak usia 4-5 tahun. Metode yang digunakandalam penelitian ini menggunakan metode jenis Penelitian Tindakan Kelas model Kemmis dan McTaggart. Dalam pengamatan ini peneliti mengumpulkan data melalui observasi, wawancara, dan dokumentasi, dan pengamatan tersebut menggunakan analisis deskriftif kuantitatif. Peneliti melalukan pengamatan sebanyak 8 kali. Pengamatan tersebut menghasilkan bahwa peningkatan mengenal angka untuk anak kelompok $A$ adanya peningkatan pada pra siklus sebesar 29,5\%, kemudian pada siklus 1 terjadi kemajuan sebesar 65\%, dan siklus II meningkat sebesar 100\%. Media beam number adalah salah satu media alternatif untuk mengenal angka usia 4-5 tahun.
\end{abstract}

Keywords:

Cognitive;

Media;

Beam number

\section{Abstract}

The pre-school period is a very meaningful stage in a person's life, which greatly influences the next stage of development, so it requires more attention to existing developmental aspects. The aspect of cognitive development is an important aspect that is maximally developed. One of the cognitive aspect developments can be done through the media beam number. The purpose of this study was to determine the application of beam numbers in the ability to recognize numbers for group $A$. The method is classroom action research by Kemmis and McTaggart models. In these observations collect data through observation, interviews, and documentation, and these observations use analysisquantitative descriptive. The researcher made 8 observations. These observations yieldthat the increasing on the students ability to recognize numbers for group A children was an increase in pre-cycle by $29.5 \%$, then in cycle 1 there was an increase of 65\%, and in cycle II increased by $100 \%$. Beam number media is one of the alternative media to recognize number for 4-5 years old children. 


\section{PENDAHULUAN}

Anak usia dini merupakan individu yang memiliki karakteristik yang unik dan rasa ingin tahu yang tinggi. Anak usia dini ibarat sebuat kertas yang masih kosong. Anak usia dini memerlukan pendidikan yang bisa memberikan stimulasi-stimulasi yang baik agar perkembangan dan pertumbuhan anak tercapai sesuai dengan tahapannya. Maka dari itu seorang guru atau orang tua harus memberikan stimuliasi-stimulasi yang baik dan menarik untuk anak agar anak ingin melakakukannya.

Perkembangan pada masa pra sekolah salah satunya adalah perkembangan kognitif karena perkembangan kognitif adalah kemampuan dimana anak harus berfikir lebih mendalam dan anak dapat memecahkan masalahnya sendiri, dengan meningkatnya kemampuan kognitif ini memudahkan anak untuk lebih memahami pengetahuan umum yang lebih kompleks, agar anak mengetahui manfaat dalam kehidupan seharihari anak di lingkungan Masyarakat (Novitasari \& Fauziddin, 2020, p. 806). Beberapa sasaran strategis tersebut adalah upaya mengembangkan kemampuan berpikir dan mengolah perolehan belajar anak, menemukan berbagai macam alternatif memecahkan logika berhitung, mencerna informasi, mengelompokan, serta menyiapkan berpikir teliti (Depdiknas, 2007, p. 2). Perkembangan Kognitif adalah sesuatu yang dengan keceradasan (Triani et al., 2014, p. 2) Dapat disimpulkan perkembangan kognitif kemampuan untuk memecahkan suatu masalah. Kemampuan perkembangan kognitif ini salah satunya adalah perkembangan dalam memgenal angka. Kegiatan mengenal angka pada masa ini sudah dilakukan pada pendidikan jalur formal maupun jalur non formal.

Kemampuan kognitif dikembangan pada anak pra sekolah yaitu mengenal angka. Pada anak usia ini tidak diperbolehkan untuk belajar berhitung namun anak usia dini hanya dibolehkan untuk mengenalkannya saja (Ernawati, 2015, p. 5). Sadar bahwa aspek perkembangan kognitif pada anak pra sekolah itu penting, maka kemampuan kognitif seperti pembelajaran mengenal angka dalam kehidupan sehari-hari, harus dilaksanakan pada masa ini (Ayu, 2016, p. 61). Jadi seorang guru untuk anak usia dini tidak memperbolehkan anak untuk belajar berhitung. Pemilihan media untuk seorang guru mengenalkan konsep angka pada anak itu harus menarik karena media yang digunakan untuk mengajar memiliki arti yang sangat berperan terhadap keberhasilan atau tidaknya tujuan pembelajaran karena, tanpa alat bantu yang menyenangkan mengakibatkan pembelajaran tidak berhasil terlaksanan dengan baik. Pemilihan sarana untuk memberikan informasi harus memiliki arah, materi, dan bentuk kegiatan belajar yang akan digunakan (Depdiknas, 2007, pp. 1-2). Dalam penelitian terdahulu yang diteliti oleh Astuti pada tahun 2016 dengan judul "Peningkatakan Kemampuan Anak Mengenal Konsep Bilangan Melalui Permainan Kartu Angka di Kelompok B TK Aisyiyah Pulau Payung Kecamatan Rumbio Jaya” dalam jrunal PAUD Tambusai, mengatakan bahwa dengan menggunakan media permainan kartu angka dapat meningkatkan kemampuan kognitif anak khususnya mengenal angka karena peserta didik saat mengikuti pembelajaran, anak dengan mudah dan menyenangkan (Astuti, 2016, pp. 94-95). Seperti yang dikemukakan oleh Conny dalam Jurnal Rianti pembelajaran pada anak pra sekolah yaitu belajar sambil bermain (Ai Yati, Sumiyati, 2020, p. 593). Oleh karena itu masih banyak seorang guru yang tidak menggunakan media hanya memanfaatkan lembar kerja anak yang telah disediakan di sekolah, atau alat tulis lainnya (Rianti, 2016, p. 37).

Peneliti saat melakukan pengamatan, dan peneliti menemukan fakta di RA Baiturrhamna Bima Cirebon saat dilaksanakannya pembelajaran untuk mengembangkan aspek kognitif khususnya mengenal angka, anakanak mudah jenuh atau bosan, dan banyak anak yang belum bisa, hanya beberapa anak yaitu 5 dari 17 siswa atau hanya 29,5\% yang mampu mengenal konsep angka 1-10. Selama pembelajaran pengenalan angka tersebut, alat yang digunakan guru yaitu menulis di papan tulis, dan media gambar dinding seadanya di dalam ruang kelas. Maka seorang guru harus memikirkan desain dan strategi yang menarik khsusunya dalam kemampuan mengenal angka. Menurut Aqib (2017, p. 51) Kegunaan media pembelajaran itu sangat membantu atau memudahkan pendidik saat proses kegiatan belajar yang dapat membuat anak menjadi semangat belajar, dan dapat menyalurkan informasi dengan jelas untuk guru menyampaikan isi kegiatan misalnya media beam number, Maka dari itu alat bantu atau media merupakan alat bantu yang bisa merangsang daya pikir, dan keinginginan anak untuk belajar lebih giat. Alat bantu saat digunakan untuk belajar diharapkan harus menjadi alat yang mempunyai arti penting saat pembelajaran. Untuk mengatasi permasalahan tersebut peneliti memberikan alternatif untuk meningkatkan perkembangan kognitif anak khususnya mengenal angka lewat penggunaan media beam number sebagai salah satu media alternatif bagi para pendidik guna memudahkan anak untuk mengenal konsep angka 110 dan anak merasa tertarik dengan sesuatu hal yang baru diterapkannya media kotak angka tersebut, maka akan dapat mengembangkan kemampuan kognitif anak khususnya mengenal angka 1-10 di usia 4-5 tahun.

Dari pemaparan tersebut dapat dikemukakan permasalahan yaitu 1. Bagaimana perkembangan mengenal angka pada usia 4 sampai 5 tahun di RA Baiturrahman saat belum dan sudah dilakukan tindakan melalui media beam number, dan 2. Apakah media beam number bisa mengembangkan mengenal angka di usia 4 sampai 5 tahun.

\section{METODE}

Metode dalam pengamatan ini adalah Penelitian Tindakan Kelas melalui Model Kemmis dan Mc. Taggart. Penggunaan model penelitian ini dilakukan secara berturut-turut (tidak bisa digunakan hanya satu kali) 
agar hasil yang diinginkan maksimal (Zainal, 2014, p. 22). Menurut Suyitno dalam buku Hendriana, Penelitian Tindakan Kelas adalah tindakan yang digunakan pendidik untuk mengubah praktek-praktek kegiatan belajar yang dilakukan melalui tindakan singkat dan evaluasi kegiatan itu (Hendriana, H, 2017, p. 35).

Penelitian ini bertujuan untuk meningkatkan kemampuan kognitif khusunya kemampuan mengenal angka 1-10 pada anak usia 4 sampai 5 tahun yang melalui media beam number. Subyek yang digunakan dalam penelitian ini merupakan anak usia 4 sampai 5 tahun yang terdapat 17 siswa. Sedangkan permasalahan yang akan diteliti adalah penerapan media beam number. Dalam penelitian ini dilakukan di RA Baiturrahman Bima Cirebon selama 8 kali pertemuan. Penelitian ini mengumpulkan data menggunakan wawancara, pengamatan, dan dokumentasi, dan pengamatan ini menggunakan analisis deskriptif kuantitatif.

\section{HASIL DAN PEMBAHASAN}

Berdasarkan pengamatan yang dilakukan peneliti yang dilakukan di sebuah lembaga RA Baiturrahman Bima Cirebon sebelum melakukan tindakan yaitu Pra Siklus. Peneliti melihat bagaimana strategi guru untuk mengembangkan aspek perkembangan kognitif anak khusunya mengenal angka di usia 4 smpai 5 tahun. Karena banyak fakta pada setiap pembelajaran bidang pengembangan kognitif khsusunya mengenalkan angka pada anak, banyak anak yang mudah jenuh dan bosan karena sarana yang diberikan pendidik tidak mengasyikkan misalnya guru menulis dipapan tulis dan hanya menggunakan media gambar dinding seadanya yang berada di dalam ruang kelas. Untuk itu guru membutuhkan media yang menarik saat meningkatkan mengenal angka pada usia 4 sampai 5 tahun ini. Dalam penelitian ini saat peneliti melihat guru melakukan tindakan saat pengenalan angka itu menggunakan media gambar dinding dan papan tulis yang menghasilkan banyak siswa yang belum mampu mengenal angka khusunya 1-10 yaitu 5 dari 11 siswa atau 29,5\% dari 100\%. Hasil observasi pra siklus dapat dilihat pada gambar 1.

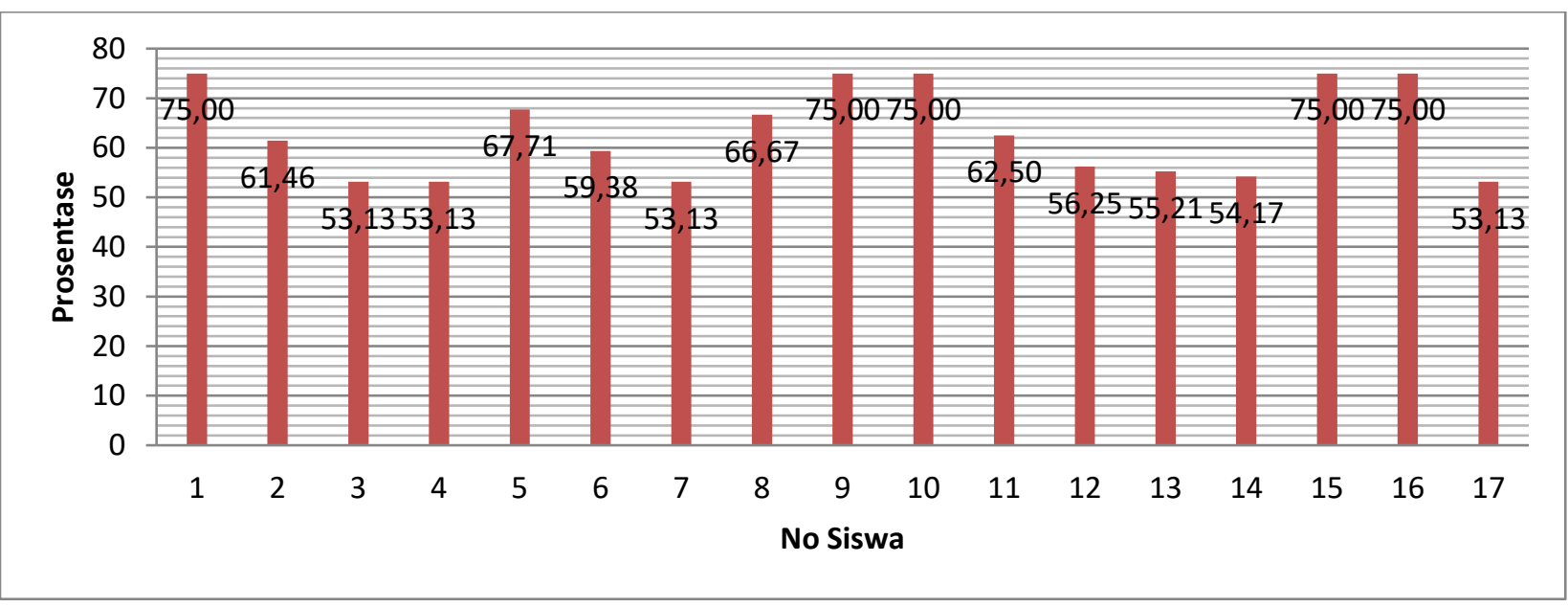

\section{Gambar 1. Prosentase Pra Siklus}

Hasil observasi tersebut mengatakan bahwa perkembangan aspek koginitf pada anak khususnya dalam mengenalkan angka di usia 4-5 tahun di RA Baiturrahman Bima Cirebon masih kurang maka harus dilakakukan tindakan lebih lanjut yaitu tindakan siklus 1 . Tabel 1 adalah proses pelaksanaan Siklus 1 yaitu penerapan media beam number pada kelompok A di RA Baiturrahman Bima Cirebon.

Berdasarkan hasil pengamatan pelaksaan media beam number tersebut yang dilakukan selama 4 kali pertemuan. Penelitian ini peneliti meminta bantuan kepada guru dalam melaksanakan kegiatan mengenal angka 1-10 pada anak kelas A usia 4-5 tahun menggunakan media beam number. Pada tahapan penelitian ini tingkat antusiasme anak yang mengikuti kegiatan pembelajaran, anak berani untuk mengikuti pembelajaran ini dan perkembangan hasil belajar anak. Stategi pendidik saat kegiatan pada siklus 1 terlaksana dengan baik dalam menyampaikan pembelajaran sesuai RPPH, memotivasi anak, serta melaksanakan tindak lanjut, dan terdapat peningkatan dalam kemampuan mengenalkan angka khusunya angka 1 sampai 10 yaitu menjadi 11 siswa dari 17 siswa sama dengan 65\% dari 100\%,. Gambar 3 adalah grafik hasil perbandingan pra siklus dan siklus 1.

Adapun Refleksi dari pembelajaran saat pelaksaan siklus 1 yaitu belum adanya komunikasi antara anak dan temannya, suasana kelas yang tidak kondusif karena anak-anak tidak sabar untuk mencoba dan saling berebutan, dan presntase keberhasilan belum mencapai sesuai dengan peneliti inginkan yaitu $75 \%$ dari $100 \%$. Maka akan ditindak lanjuti dengan pelaksaan siklus ke 2. 
Tabel 1. Pelaksanaan Siklus 1

\section{Perencanaan Penerapan Penggunaan Media Beam Number di RA Baiturrahman Bima Cirebon}

Berdasarkan hasil dari data wawancara dengan guru, observasi di kelas melhat guru dan anak-anak saat melaksanakan pembelajaran, dan alat bantu observasi yaitu lembar penilaian, peneliti memperoleh data bahwa pelaksanaan media beam number di RA Baiturrahman Bima Cirebon dilakukan dengan melakukan perencanaan kegiatan yang berhubungan dengan kegiatan tersebut yang sesuai tema dan sub tema yaitu guru membuat perencanaan dengan membuat RPPM dan RPPH, agar memudahkan guru dalam melaksanakan kegiatan pembelajaran.

Pelaksanaan Penerapan Penggunaan Media Beam Number di RA Baiturrhaman Bima Cirebon dengan melakukan kegiatan mengaji dan membaca setelah itu berbaris di halaman sekolah dengan melakukan yaitu bernyanyi, membaca do'a-do'a pendek, dan melakukan bincangbincang dengan anak dan guru memberitahu tentang isi pokok kegiatan belajar.

b. Kegiatan $\quad$ Pada Pelaksanaan ini guru menjelaskan tema yang akan dipelajari dalam pembelajaraan saat Pelaksanaan Media itu. Untuk penerapan media beam number dapat disesuaikan dengan tema yang akan Beam Number dilaksanakan, untuk Kegiatan yang pertama dalam penerapan media beam number pertama guru menjelaskan apa itu media beam number, kemudian guru menjelaskan serta memberi contoh cara penerapan media beam number. Setelah anak memahami guru memberikan tugas mengenal konsep angka 1-10 yang sangat sederhana dengan cara memasukkan potongan balok angka ke dalam beam number sesuai angka yang tertera pada beam number tersebut lalu menyebutkannya.

Penerapan media beam number tersebut, guru tidak lupa menerapkan beberapa metode seperti metode bernyanyi dan metode demonstrasi, metode tersebut disesuaikan dengan kondisi anak-anak didalam kelas, penerapan metode dalam kegiatan agar pembelajaran tidak monoton, sehingga anak akan mengikuti pembelajaran dengan baik dan sebagai dorongan agar anak tidak merasa bosan.

c. Kegiatan Istirahat Sebelum anak-anak melakukan kegiatan istirahat anak-anak berdo'a terlebih dahulu dan bernyayi. Dari hasil yang dilihat peneliti, anak-anak berbaris melakukan membersihkan jarijari, setelah membersihkan jari-jari, lalu menyantap bekal bersama di dalam kelas, pada istirahat guru melatih anak agar mau berbagi dengan temanya sehingga kebersaamaan anak mampu terlihat. Setelah selesai makan anak-anak mencuci kembali tangannya dan setelah itu anak-anak diberi kebebasan untuk bermain di luar namun tetap dalam pengawasan guru dan wali murid.

d. Kegiatan Penutup Kegiatan penutup anak kembali duduk melingkar di karpet seperti saat pembelajaran dimulai, Guru mengulas kembali pembelajaran yang telah dilakukan, dalam kegiatan penutup anakanak diharapkan bisa menjawab pertanyaan-pertanyaan sederhana dari guru mengenai kegiatan yang telah dilaksanakan dilakukan atau diajarkan, yang bertujuan agar dapat menilai anak apakah anak mampu menjawab pertanyaan. Kemudian guru memberi kesempatan untuk anak yang berani bercerita tentang tugas apa saja yang telah dilakukan dengan memberikan reward agar anak ingin melakukan kegiatan di hari berikutnya.

Gambar 2 adalah pelaksanaan kegiatan pelaksanaan penerapan media beam number

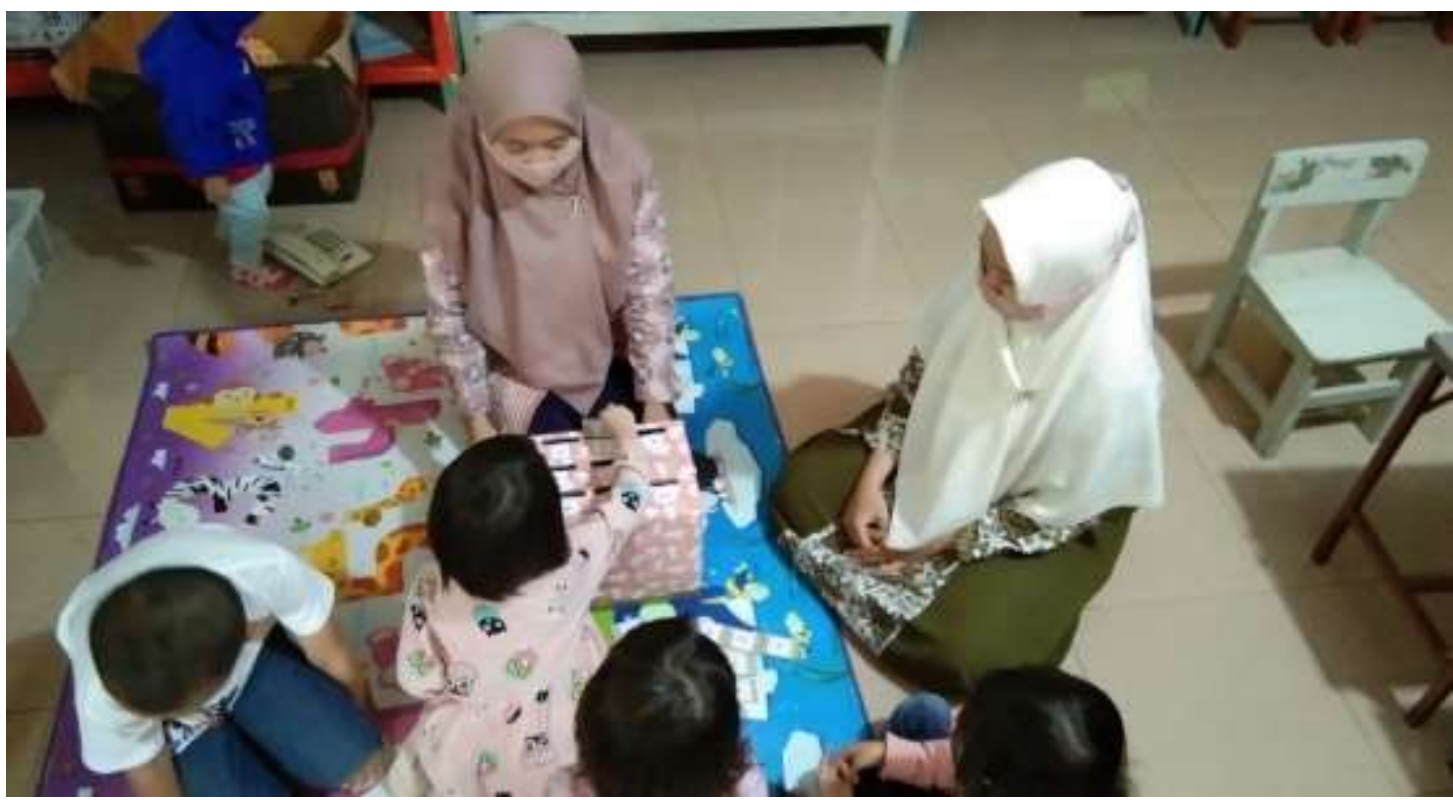

Gambar 2. Siklus 1 Pelaksanaan Media Beam Number saat Pembelajaran 


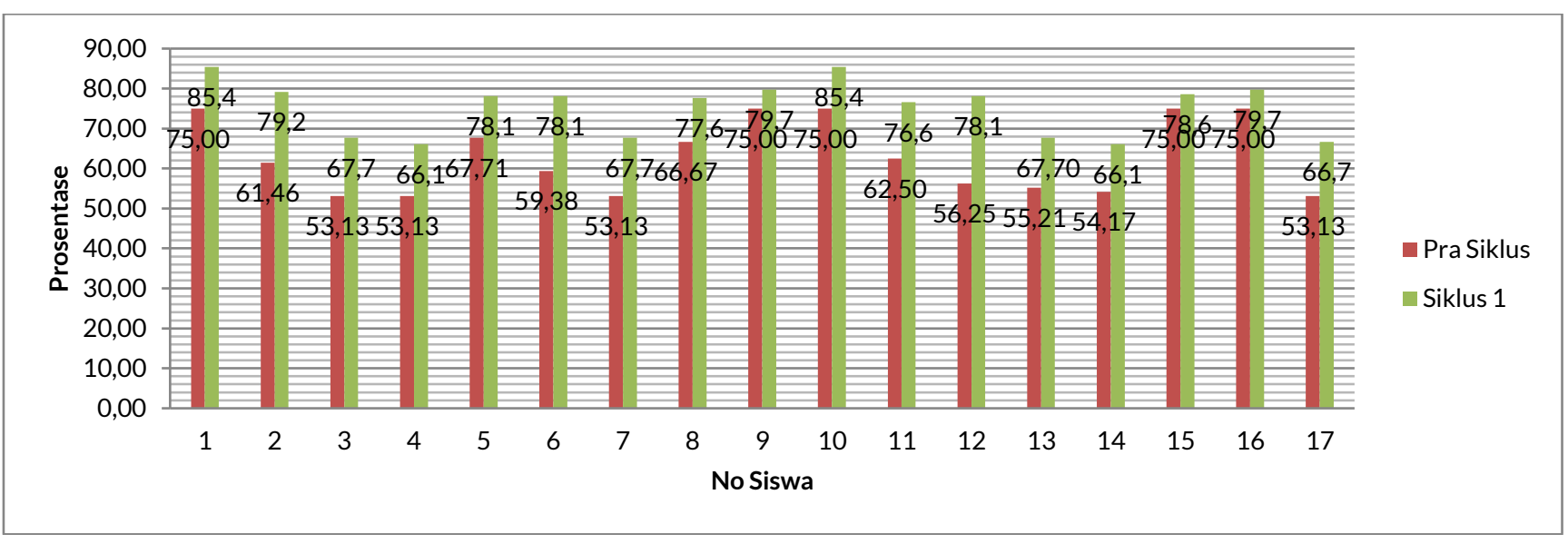

\section{Gambar 3. Grafik Perbedaan Hasil Pra Tindakan dan Tindakan ke 1}

Pelaksaan media kotak angka pada siklus ke 2 sama halnya dengan pelaksanaan pada siklus pertama dilakukan dengan 4 kali pertemuan sebagaimana pada tabel 2 .

\section{Tabel 2. Pelaksanaan Siklus 2}

\section{Perencanaan Penerapan Penggunaan Media Beam Number di RA Baiturrahman Bima Cirebon}

Berdasarkan hasil dari data wawancara dengan guru, observasi di kelas melhat guru dan anak-anak saat melaksanakan pembelajaran, dan alat bantu observasi yaitu lembar penilaian, peneliti memperoleh data bahwa pelaksanaan media beam number di RA Baiturrahman Bima Cirebon dilakukan dengan melakukan perencanaan kegiatan yang berhubungan dengan kegiatan tersebut yang sesuai tema dan sub tema yaitu guru membuat perencanaan dengan membuat RPPM dan RPPH, agar memudahkan guru dalam melaksanakan kegiatan pembelajaran.

Pelaksanaan Penerapan Penggunaan Media Beam Number di RA Baiturrhaman Bima Cirebon

a. Kegiatan Awal $\quad$ Kegiatan awal diawali dengan memberikan simulasi pada anak, pembelajaran awal dilakukan dengan melakukan kegiatan mengaji dan membaca setelah itu berbaris di halaman sekolah dengan melakukan yaitu bernyanyi, membaca do'a-do'a pendek, dan melakukan bincang-bincang dengan anak dan guru memberitahu tentang isi pokok kegiatan belajar.

b. Kegiatan
Pelaksanaan Media
Beam Number

Pada pelaksanaan ini guru menjelaskan tema yang akan dipelajari dalam pembelajaraan saat Pelaksanaan Media itu. Namun sedikiti berbeda saat pelaksanaan penerapan media beam number pada siklus kedua ini yaitu guru menyediakan reward untuk anak-anak yang dapat melaksanakannya dengan baik, dan memberikan reward mengharapkan agar anak-anak semangat dan anakanak mengikutinya dengan tertib, saat guru menjelaskan kembali bagaimana pelaksanaan media beam number, kemudian guru menjelaskan serta memberi contoh cara penerapan media beam number. Setelah anak memahami guru memberikan tugas mengenal konsep angka 1-10 yang sangat sederhana dengan cara memasukkan potongan balok angka ke dalam beam number sesuai angka yang tertera pada beam number tersebut lalu menyebutkannya.

c. Kegiatan Istirahat Pada kegiatan istrirahat ini sama halnya dengan siklus satu yaitu anak-anak melakukan untuk makan bersama. Namun sebelum makan bersama, anak-anak terlebih dahulu untuk berdo'a sebleum maka, lalu membersihkan atau mencuci tangan, setelah mencuci tangan anak-anak makan bersama. Dalam kegiatan makan bersama ini melatih anak untuk berbagi dengan teman-temannya.

d. Kegiatan Penutup $\quad$ Pada Kegiatan penutup sama halnya dengan siklus pertama yaitu guru mengulas kembali pembelajaran yang telah dilakukan pada hari tersebut, dan guru mengharapkan anak-anak mampu menjawab dengan benar dan baik.

Gambar pelaksanaan kegiatan penerapan media beam number sebagaimana dapat dilihat pada gambar 4 . Berdasarkan hasil pengamatan pada pelaksanaan siklus kedua, pada siklus ke 2 ini sangat baik yaitu guru sudah maksimal melaksanakan kegiatan dan menggunakan waktu sesuai RPPH dan siswa juga merespon menjadi lebih baik, ini terbukti siswa jadi lebih aktif dan semangat dalam mengikuti kegiatan media beam number tersebut. Pada pelaksanaan siklus kedua ini lebih banyak yang meningkat yaitu 17 anak atau 100\% berhasil meningkat dalam mengenal angka khususnya angka 1-10. Gamabr 5 adalah perbedaan hasil pra tindakan, tindakan ke 1, dan tindakan ke 2.

Refleksi dari pelaksanaan siklus kedua yaitu anak lebih aktif dan antusias, guru lebih maksimal dalam mengelola pembelajaran, dan anak lebih berani berekpresi. Maka tindakan penelitian ini diberhentikan sampai siklus kedua. Dapat disimpulkan dari hasil pengamatan pra tindakan (siklus), tindakan pertama, dan tindakan 
kedua adanya peningkatan kemampuan mengenal angka khususnya angka 1-10 pada usia 4 sampai 5 tahun melalui media beam number karena peran guru sangatlah penting dalam meningkatkan pembelajaran pada anak dalam pengenalan angka saat usia ini dan guru harus membuat pembelajaran menjadi bervariatif dan menyenangkan sehingga anak tidak jenuh dan semangat dalam ikut serta kegiatan belajar, karena pemilihan sarana berpengaruh terhadap hasil pencapaian mengembangkan mengenal angka saat usia ini.

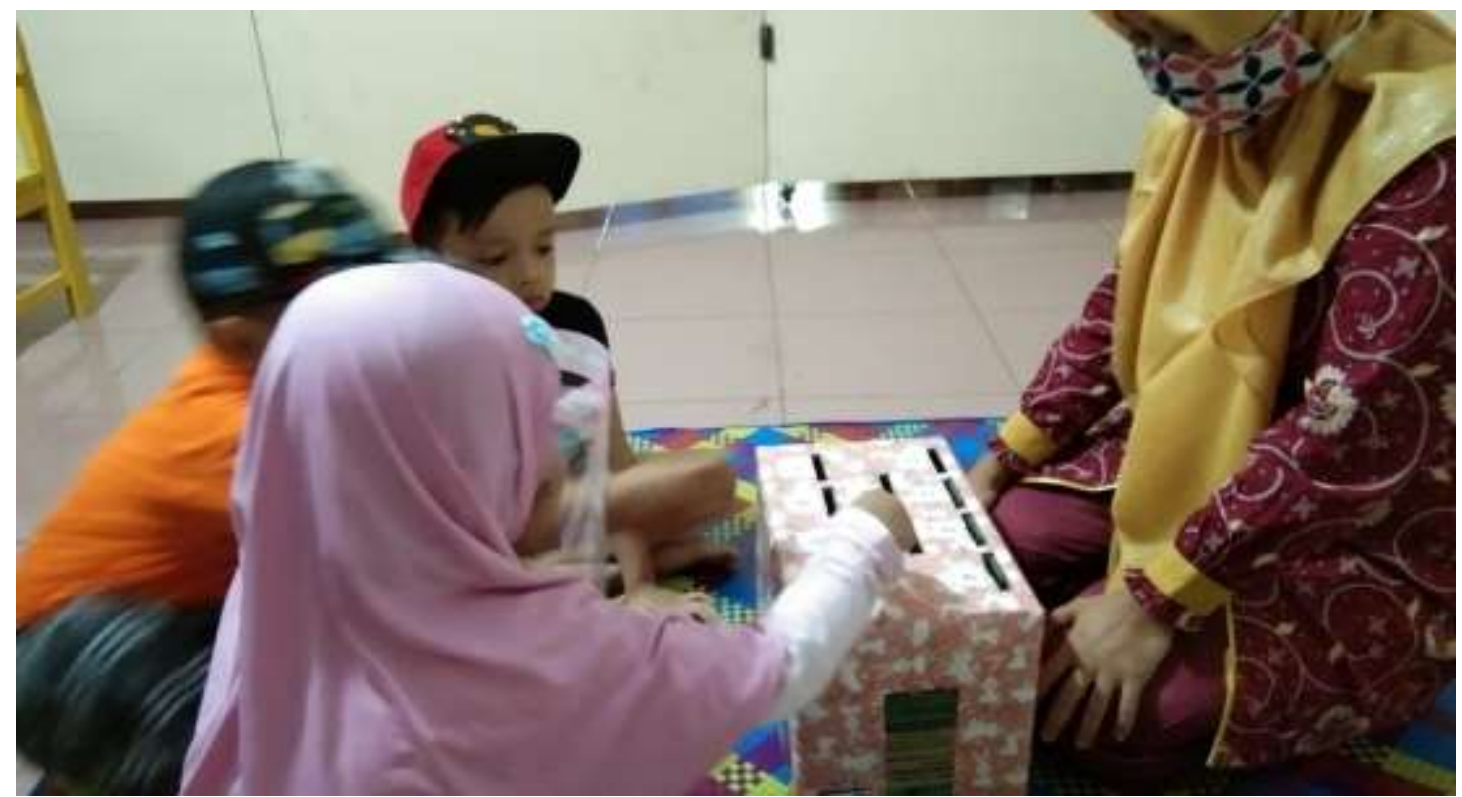

Gambar 4. Siklus 2 Pelaksanaan Media Beam Number saat Pembelajaran

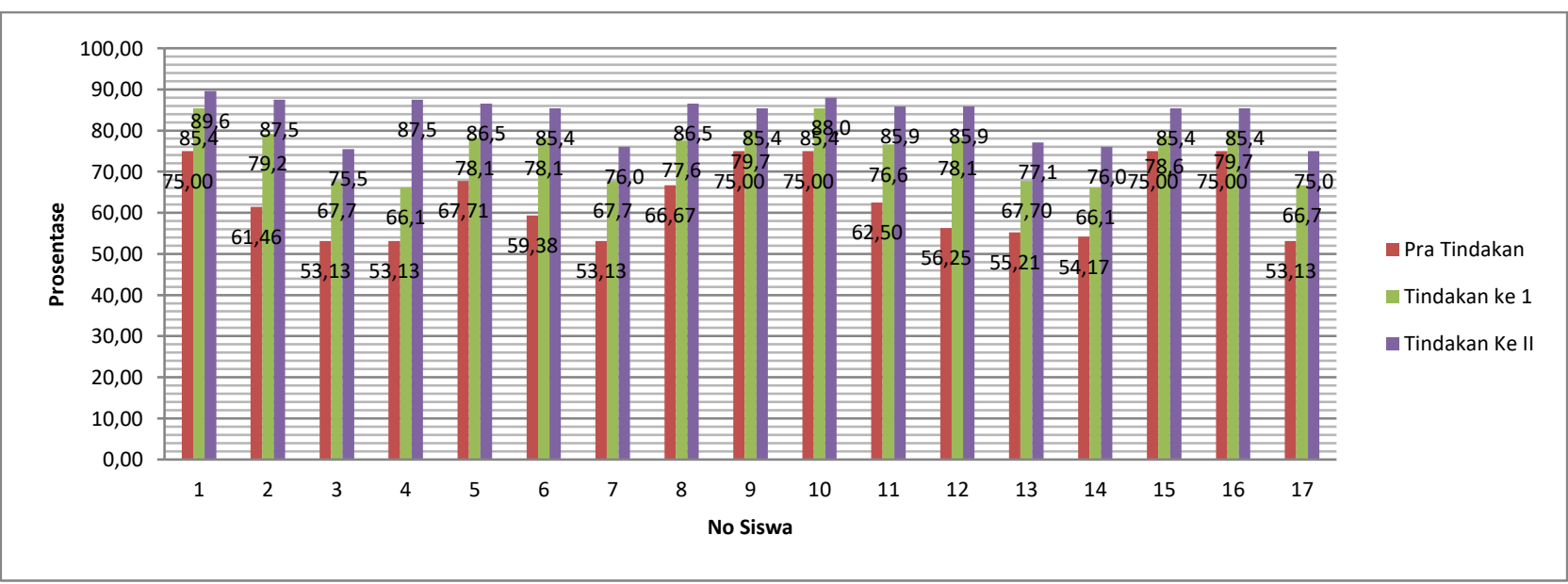

Gambar 5. Perbedaan Hasil Pra Tindakan, Tindakan ke 1, dan Tindakan ke II

\section{Kemampuan Kognisi Anak Usia Dini}

Kognisi adalah salah satu tingkat pencapaian terhadap anak karena berhubungan langsung dalam pendidikan (Supriadi, 2013, p. 99). Kognitif juga merupakan kemampuan yang memiliki peran sepanjang kehidupan seorang individu. Perkembangan kognitif anak berawal dari lingkungan keluarga. Anak mulai belajar dari mendengar, mengenal benda sekitar yang ada di dalam keluarganya. Stimulasi yang diberikan lingkungan keluarga sangat berpengaruh dalam perkembangan kognitif anak. Oleh sebab itu saat stimulus diberikan secara maksimal, maka aspek ini akan berkembang baik. Tetapi sebaliknya saat diberikan tidak secara optimal, besar kemungkinan anak akan mengalami keterlambatan pada aspek perkembangan kognitif. Perkembangan kognitif anak dimulai sejak bayi. Menurut Piaget faktor yang mempengaruhi pertumbuhan intektual adalah social (Fardiah et al., 2019, p. 135). Oleh karena itu evaluasi pada perkembangan kognitif anak harus segera dilakukan sejak dini jika anak tidak memahami perintah sederhana sampai usia 12 bulan sejak lahir, tidak memahami petunjuk sederhana sampai usia 18 bulan, tidak mencoba mencari benda yang disembunyikan sampai usia 2 tahun, tidak mampu menyusun balok sampai usia 3 tahun dan merasa sangat sulit untuk mengerjakan tugas pada usia 4-5 tahun (Ahmet Yasin, Hatice Aksu, Erdogan, 2017, p. 23). 
Menurut Wiresti dan Suyadi, (2020, p. 132 ) salah satu perkembangan kognitif pada anak usia 4 sampai 5 tahun yaitu anak mampu mengetahui benda menurut manfaatnya misalnya penghapus untuk menghapus, anak mampu bermain simbolik misalnya penghapus sebagai telpon, anak mampu mengetahui siang dan malam, dan anak mampu mengenal angka 1-10 dan lain sebagainya. Jadi anak pada usia 4 sampai 5 tahun anak-anak harus mampu mengenal angka 1-10, jika pada usia tersebut belum dapat atau mampu mengenal angka 1-10, maka nak tersebut harus diberi stimulasi secara berulang-ulang, agar kemampuan anak dalam mengenal anakha 1-10 terus meningkat.

\section{Media Pembelajaran}

Media secara Bahasa adalah alat bantu. Dengan demikian Media merupakan alat yang dapat dijadikan penyalur informasi pembelajaran (Syaifudin Bahri Djamarah, 2014, p. 120). Media pembelajaran adalah alat yang dijadikan pengantar informasi untuk anak berpikir yang akhirnya terjadi keinginan anak memperoleh ilmu. Menurut Istiqomah (2019, p. 18) sarana pembelajaran adalah alat penyalur informasi untuk mengajar. Media pembelajaran juga dapat menjadi pengantar informasi dengan untuk anak yang memiliki keterbatasan pengelihatan (Putri et al., 2020, p. 655). Menurut Aqib (2017, p. 51).kegunaan media pembelajaran itu sangat membantu atau memudahkan pendidik saat proses kegiatan belajar yang dapat membuat anak menjadi semangat belajar, dan dapat menyalurkan informasi dengan jelas untuk guru menyampaikan isi kegiatan.

Berdasarkan pemaparan di atas media pembelajaran adalah alat penyalur informasi yang bisa dilakukan guru atau disalurkan guru dalam merangsang terjadinya kegiatan belajar. Dilihat dari hasil penelitian juga bahwasannya media pembelajaran itu sangat penting sebagai alat bantu untuk guru karena dengan adanya media pembelajaran, anak-anak tidak mudah bosan dan jenuh dibandingkan dengan tidak adanya media pembelajaran, anak-anak mudah bosan dan jenuh saat pelaksanaan pembelajaran.

\section{Beam Number}

Menurut Patrizal (2013, p. 236) beam number adalah permainan yang dijadikan media oleh guru dalam mempermudah seorang guru mengenalkan konsep angka 1-10 untuk usia pra sekolah saat pembelajaran sehingga peserta didik tak merasa bosan, jenuh, dan dapat membuat anak semakin semangat belajar saat pembelajaran.

Cara guru untuk membuat beam number ini sangatlah mudah dengan bahan-bahan bekas yang berada di sekitar lingkungan sekolah yaitu Guru menyiapkan kardus bekas, gunting atau cutter, lem, kertas kado, lakban dan selembar kertas yang terdapat angka-angka yaitu 1-10, kemudian lakbanlah kardus agar menjadi sebuah kotak yang utuh kembali, kemudian bungkuslah kardus dengan kertas kado agar menjadi cantic, kemudian lubangkan kardus sebanyak 10 lubang dengan bentuk persegi panjang, kemudian buatlah kotak-kotak kecil, kemudian guntinglah selembar kertas tersebut yang berisi angka 1-10, dan kemudian tempelkan angka-angka tersebut di atas kardus dan kotak-kotak kecil tersebut.

Cara guru untuk menggunakan beam number tersebut untuk mempermudah anak mengenal konsep angka yaitu pendidik memberikan instruksi kepada anak-anak berkumpul dibawah, kemudian guru menyebutkan angka yang ingin guru sebut, kemudian anak-anak mencari angka yang sesuai ibu guru sebutkan, kemudian anak-anak memasukkan kotak-kotak kecil ke dalam kardus yang sudah tertera angka-angka, dan kemudian anak-anak menyebutkan angka tersebut. Dilihat dari hasil penelitian juga bahwasannya saat guru melaksanakan kegaiatan pembelajaran khusunya dalam mengenal angka 1-10 menggunakan media pembelajaran beam number yaitu mampu meningkatkan kemampuan kognitif anak khususnya mengenal angka 1-10 karena saat guru melaksanakan pembelajaran yaitu mengenal angka 1-10, guru memberikan media yang baru yang membuat anak menjadi semangat, tidak bosan, dan jenuh saat pembelajaran, sehingga anak-anak mampu mengikuti pembelajaran dengan baik.

\section{SIMPULAN}

Dapat disimpulkan dari hasil penelitian yang telah dipaparkan bahwasannya peningkatan kemampuan kogitif khususnya mengenal angka 1 sampai 10 pada usia 4 sampai 5 tahun sangat efektif saat distimulus atau dilakukan melalui media beam number di RA Baiturrahman Bima Cirebon karena anak merasa ini hal yang baru dilakukan oleh guru, dan anak-anak tidak bosan karena sambil bermain dibandingkan sebelum menggunakan media beam number tersebut guru menggunakan media dinding seadanya di kelas, anak-anak merasa mudah bosan, jenuh, dan tidak bersemangat untuk belajar karena guru mengajarkannya dengan cara monoton.

\section{UCAPAN TERIMA KASIH}

Penulis mengucapkan banyak-banyak terima kasih kepada Allah SWT yang sudah memberikan penulis kesehatan, dan semua pihak yang telah membantu penulis dalam penelitian ini. 


\section{DAFTAR PUSTAKA}

Ahmet Yasin, Hatice Aksu, Erdogan, B. G. O. (2017). Speech and Language Delay In Childnood. ENT Update, 7(1), 23. https://doi.org/10.2399/jmu.2017001004

Ai Yati, Sumiyati, K. (2020). Peningkatan Kemampuan Mengenal Huruf melalui Media Permainan Kotak Huruf pada Kelompok B. Jurnal Ceria, 3(6), 593.

Aqib, Z. (2017). Model-Model, Media, dan Strategi Pembelajaran Kontekstual (Inovatif). CV. Yrama Widya.

Astuti. (2016). Peningkatakan Kemampuan Anak Mengenal Konsep Bilangan Melalui Permainan Kartu Angka di Kelompok B TK Aisyiyah Pulau Payung Kecamatan Rumbio Jaya. PAUD Tambusai, 2(1), 94-95.

Ayu, C. (2016). Meningkatkan Kemampuan Kognitif Anak dalam Kegiatan Membilang dengan Metode Bermain Media Kartu Angka pada Anak Usia 4-5 Tahun di TK Taqifa Bangkinang. Jurnal Paud Tambusai, 2(2), 61.

Depdiknas. (2007). Pedoman Bermain Berhitung Permulaan di Taman Kanak-Kanak. Dirjen Dikdasmen.

Ernawati, I. (2015). Mengembangkan Kemampuan Mengenal Konsep Angka 1-10 Melalui Pengugunaan Media Kotak Ajaib pada Anak Kelompok A TK Perdana Desa Tiron Kecamatan Banyakan Kabupaten Kediri. Universitas Nusantara PGRI Kediri.

Fardiah, F., Murwani, S., \& Dhieni, N. (2019). Meningkatkan Kemampuan Kognitif Anak Usia Dini melalui Pembelajaran Sains. Jurnal Obsesi: Jurnal Pendidikan Anak Usia Dini, 4(1), 135. https://doi.org/10.31004/obsesi.v4i1.254

Hendriana, H, dan A. M. (2017). Langkah Praktis Penelitian Tindakan Kelas Bagi Guru. PT Refika Aditama.

Istiqomah, S. (2019). Pengaruh Media Kotak Angka Terhadap Hasil Belajar Siswa pada Materi Perkalian dalam Pembelajaran Matematika Kelas 3 SDN 09 Rejang Lebong. IAIN Bengkulu.

Ketut Triani, Made Suarjana, L. A. T. (2014). Penerapan Metode Pembelajaran Tugas Berbantuan Media Kotak Angka Untuk Meningkatkan Kemampuan Kognitif Anak TK. E-Jurnal PG PAUD Univeristas Pendidikan Ganesha, 2(1), 2.

Novitasari, Y., \& Fauziddin, M. (2020). Perkembangan Kognitif Bidang Auditori pada Anak Usia Dini. Jurnal Obsesi : Jurnal Pendidikan Anak Usia Dini, 5(1), 806. https://doi.org/10.31004/obsesi.v5i1.640

Patrizal, I. (2013). Meningkatkan Kemampuan Mengenal Konsep Angka Melalui Media Kotak Angka Bagi Anak Berkesulitan Belajar. Jurnal IImiah Pendidikan Khusus, 2(3), 236.

Putri, D. K., Handayani, M., \& Akbar, Z. (2020). Pengaruh Media Pembelajaran dan Motivasi Diri terhadap Keterlibatan Orang Tua dalam Pendidikan Anak. Jurnal Obsesi : Jurnal Pendidikan Anak Usia Dini, 4(2), 655. https://doi.org/10.31004/obsesi.v4i2.418

Rianti, W. (2016). Meningkatkan Kemampuan Mengenal Lambang Bilangan Melalui Permainan Tata Angka pada Anak Usia DIni. PAUD Tambusai, 02(02), 37.

Supriadi, O. (2013). Perkembangan Peserta Didik. Kurnia Kalam Semesta.

Syaifudin Bahri Djamarah, A. Z. (2014). Strategi Belajar Mengajar. PT. Rineka Cipta.

Wiresti, R. D., \& Suyadi. (2020). Implementasi Permainan Jump Count Melalui Abacus Tangga Untuk Meningkatkan Perkembangan Kognitif Anak Usia Dini Di Masa Pandemi. Bunayya: Jurnal Pendidikan Anak, VI(2), 129-140. https://doi.org/10.24127/j-sanak.v2i01.366

Zainal, A. dan. (2014). Penelitian Tindakan Kelas. CV. Yrama Widya. 